\title{
The censorship and suppression of Cork's nationalist and loyalist newspapers during the Irish Revolution, 1916-1923
}

\author{
Alan McCarthy \\ School of History, UCC
}

\section{Introduction}

The Irish Revolution was an epochal period that saw the Irish nationalist movement seek to obtain independence from the British Empire. It has received extensive scholarly attention, particularly the century-shaping 1916 Rising, the guerrilla war campaign that coloured the War of Independence 1919-1921, and an implosive Civil War between those for and against the Anglo-Irish Treaty, that raged between 1922-1923 and continues to shape present-day politics in Ireland. Key to understanding Cork, the epicentre of revolutionary activity post-1916, is an engagement with its widely-read newspapers of the time. During this period West Cork's Southern Star and Skibbereen Eagle, and Cork City institutions, the Cork Examiner and Cork Constitution, acted as central actors, in conjunction with their role as reporters, in the equally significant battle for hearts and minds. The consequence of the key propaganda role played by these papers would be intense censorship and suppression by both Crown Forces and the military wing of the Irish nationalist movement, the IRA. While this may seem insignificant to present-day readers, who have unfettered and constant access to news and information, the suppression experienced by these newspapers occurred at a time when newspapers were integral to the dissemination of ideas and opinions, owing to the absence of competition from the internet, radio or television. Moreover, the media dimension to the Irish Revolution has often been overlooked by academic historians, who tend to view these papers as historical sources as opposed to the historical forces that they were. Consequently, the aim of this research is to engage with the suppression of these papers, which represented a devastating curtailment of freedom of speech, as well as highlighting the influential role these papers played in moulding public opinion during this pivotal period in Irish history.

\section{West Cork}

The Skibbereen Eagle was the elder statesman of the West Cork papers. Originally a foursheet paper containing mainly advertisements and snippets of local news, the Eagle has the distinction, rather ironically, of being the first publication to publish a poetic verse by famed Fenian Jeremiah O'Donovan Rossa. Following a brief period of championing 
John Redmond's Irish Parliamentary Party, the savagely "anti-republican" Eagle would become radicalised during this period, becoming more outwardly loyalist in tonal quality. Such were the efforts of the Eagle that Managing Director Eddie Swanton would, in his compensation application to the Irish Grants Commission, claim that the newspaper

"in its own area did more for the support of the British Empire than any other newspaper in Ireland."

Intended to oppose the Eagle's advocacy of maintaining the Union between Britain and Ireland, the Southern Star was founded by John and Florence O'Sullivan in 1889. Such was the extent of the suppression experienced by the paper during this period that Liam O'Regan would write in the Southern Star's Centenary Supplement that

"The Southern Star can claim a special interest in press freedom because without contradiction, it can claim to be Ireland's most suppressed newspaper during the War of Independence."

The adoption of a determinedly more radical nationalist outlook in the aftermath of the 1916 Rising led to the Star's first experience of suppression under the orders of General Maxwell. Following its acquisition by Sinn Féin, the political party of the revolutionary movement, the Star became a veritable 'who's who' of Cork republicans, as influential figures, such as Michael Collins, became shareholders, along with the employment of other notable individuals like Gaelic League activist Peadar O'Hourihan, T.D. Sean Hayes, and labour leader Tadgh Barry, along with future Minister for Finance Ernest Blythe; Seamus O'Brien, who would go on to marry James Connolly's daughter Nora, served for a period as office manager.

Increased radicalisation resulted in increased suppression, which was often met by an air of inevitability. The Star was shut down on four more occasions by the British administration during this period, usually for breaching the Defence of the Realm Act (DORA), including lengthy closure during 1918, 1919 and 1920. Brought into being following the outbreak of World War I in August 1914, DORA afforded the British state a host of measures, formalised in an extensive set of Defence of the Realm Regulations (DRR) which, most importantly, permitted the seizure of printing presses and made sedition in print a court-martial-worthy offence, proving a massive hindrance to the republican press.

While DORA was relaxed in 1919, the dumping of machinery belonging to the Eagle into the River Ilen in 1920 by the IRA served to be another unwelcome reminder of the advent of censorship and suppression in Ireland. The impact of such actions is showcased by the revelatory comments of Eddie Swanton to the Irish Grants Commission, in which he claims that

"circulation was continued only with the greatest difficulty" as "attack after attack was made on the paper." 
The Eagle's first taste of suppression arrived in 1917, with company secretary James O'Driscoll recalling that

"the Eagle office was raided by armed and disguised men, the machinery broken and considerable damage and confusion caused."

The plant of the Eagle would be destroyed again in early 1918 in light of its continued "anti-National and pro-British" general policy, while P. Sheehy, the "brilliant poet editor of the Eagle", suffered the indignity of being tarred and feathered. The paper also had a boycott imposed upon it during 1920, with copies of the weekly paper being stolen and burned publicly in some instances. The Eagle, however, was only compensated for the value of the copies burned during the boycott, thus ignoring the significant loss of income caused by the disruption to its circulation, as the paper's irregular appearance discouraged regular subscribers from buying it. As a result, this West Cork weekly found itself creeping towards insolvency. Continued suppression and agitation from the IRA would eventually force the closure of the Eagle offices in July 1922.

\section{Cork City}

The Eagle's political mirror in the City was the Cork Constitution. While R.B. McDowell noted that the Constitution

"forcefully advocated the unionist cause in the south,"

to present-day readers the name Cork Constitution is more readily associated with the rugby team of the same name. Founded in 1892, the rugby team was bank-rolled by Managing Director and Editor H.L. Tivy, who also served as the club's first president, while several players would enlist to fight for 'King and Country' in World War I. The Constitution's sparring partner for close to a century was the Cork Examiner. Within the offices of the Examiner there existed an opposition to militarism since the days of its founder, John Francis Maguire. Situated at No. 95 Patrick Street, Editor George Crosbie and his staff witnessed more violence than any other paper in Cork, a point overlooked by those who have attempted to explain the Examiner's pacifistic approach to the revolutionary period, with the paper condemning the violent activities of the IRA and forces of the Crown in equal measure. In December 1920 alone the staff witnessed Auxiliary police officers flogging people outside the Examiner office, while the city centre itself would be razed to rubble mere days later in the infamous 'Burning of Cork.'

The Examiner suffered under the Crown's censorship for the first time in September 1919 for advertising the Dáil Loan. This marked the beginning of a few intense years of agitation which would see the paper raided by the IRA and harassed by the Crown, while both republicans and the 'Anti-Sinn Fein Society', a loyalist group considered to be a front for unofficial reprisals by Crown Forces, forced the paper's staff to insert notices into the paper at gunpoint. In 1923, republicans burned Crosbie's home to the ground, while office 
manager Denis McGrath was shot and seriously wounded. Of the papers concerned, the Constitution would be the only one to survive the War of Independence largely unscathed. Like the Eagle and the Examiner, the Constitution would have its presses wrecked by the IRA in early 1920, while Tivy was ordered to leave the country by militant republicans. Later in the year Tivy received a letter, informing him to prepare for execution. Undaunted, he maintained his role and continued to criticise the IRA. The anti-Treaty faction would, however, assume control of Cork during the Civil War, with republicans establishing a rigid censorship over both the Constitution and Examiner during the summer of 1922. Unwilling to submit to this censorship, Tivy shut down his paper indefinitely in July of that year, mirroring the decision of the Eagle, which had closed its doors a week earlier due to continued harassment. Weeks later the offices of both the Constitution and Examiner were destroyed by anti-Treatyites evacuating the city following the amphibious landing of Free State troops in Cork.

\section{Conclusion}

The closure of Cork's loyalist newspapers, brought about by the greater severity of IRA censorship as opposed to the British administration, highlighted the furious zeal with which censorship could be conducted in this country, and represented the loss of two journals of admirable journalistic merit. In the present 'Decade of Centenaries', this research will encourage closer engagement with the role of the media in the Irish Revolution and serve as a timely reminder, at a time when we take freedom of information and the freedom to access this information for granted, that editors, reporters and journalists alike suffered grievous harassment and suppression in order to circulate the news to their respective communities.

Alan McCarthy is a First-Year PhD student in the School of History, under the supervision of Dr Donal Ó Drisceoil. The author wishes to thank both Dr Ó Drisceoil and the College of Arts, Celtic Studies and Social Sciences, who have supported this research via a PhD (Excellence) Scholarship. 